\title{
PENGARUH INKLUSI DAN LITERASI KEUANGAN SYARIAH TERHADAP PENINGKATAN JUMLAH MAHASISWA PERBANKAN SYARIAH DI KOTA BINJAI
}

\author{
Raja Sakti Putra Harahap, Shantika Dewi \\ Sekolah Tinggi Agama Islam Syeikh H. Abdul Halim Hasan Al Ishlahiyah Binjai \\ putrasafar036@gmail.com,shantikadewi20@gmail.com
}

\begin{abstract}
Knowledge of Islamic finance is growing as human needs are increasingly complex. This ability is related to personal intelligence to be effective for the realization of social welfare, which we cannot avoid, for example in determining future decisions related to short-term or long-term decisions indirectly. The purpose of this study was to determine the effect of inclusion and Islamic financial literacy on the increase in the number of Islamic banking students at STAI Al-Ishlahiyah Binjai. This research was conducted at STAI Al Ishlahiyah Binjai. The population in this study were 1373 students of Islamic banking at STAI Al-Ishlahiyah Binjai and a total sample of 93 respondents. The results obtained: 1) There is an effect of inclusion on the increase in the number of Islamic banking students $(p=0.000)$; 2) There is an effect of Islamic financial literacy on the increase in the number of Islamic banking students $(p=0.036) ; 3)$ There is an effect of inclusion and Islamic financial literacy on the increase in the number of Islamic banking students $(p=0,000)$. This proves that simultaneous inclusion, namely student financial access and Islamic financial literacy, namely understanding of Islamic finance affects the increasing number of Islamic banking students.
\end{abstract}

\section{Keywords: Inclusion, Islamic Financial Literacy, and Increasing the Number of Students}

ABSTRAK : Pengetahuan tentang keuangan syariah semakin berkembang seiring bertambahnya kebutuhan manusia yang semakin kompleks. Kemampuan yang dimiliki ini berkaitan dengan kecerdasan pribadi untuk bersikap efektif demi terwujudnya kesejahteraan masyarakat yang tidak dapat kita hindari misalnya dalam hal menentukan keputusan masa depan yang berkaitan dengan keputusan jangka pendek ataupun jangka panjang secara tidak langsung. Tujuan penelitian ini untuk mengetahui pengaruh inklusi dan literasi keuangan syariah terhadap peningkatan jumlah mahasiswa perbankan syariah di STAI Al-Ishlahiyah Binjai. Penelitian ini dilakukan di STAI Al Ishlahiyah Binjai. Populasi dalam penelitian ini adalah mahasiswa perbankan syariah di STAI AlIshlahiyah Binjai yang berjumlah 1373 orang dan jumlah sampel sebanyak 93 responden. Hasil penelitian yang diperoleh: 1) Ada pengaruh inklusi terhadap peningkatan jumlah mahasiswa perbankan syariah $(p=0,000) ; 2)$ Ada pengaruh literasi keuangan syariah terhadap peningkatan jumlah mahasiswa perbankan syariah ( $p=0,036) ; 3)$ Ada pengaruh inklusi dan literasi keuangan syariah terhadap peningkatan jumlah mahasiswa perbankan syariah $(p=0,000)$, Ini membuktikan bahwa secara simultan inklusi yakni akses keuangan mahasiswa dan literasi keuangan syariah yakni pemahaman mengenai keuangan syariah mempengaruhi meningkatnya jumlah mahasiswa perbankan syariah.

Kata Kunci : Inklusi, Literasi Keuangan Syariah, dan Peningkatan Jumlah Mahasiswa

\section{PENDAHULUAN}

Pengetahuan tentang keuangan syariah semakin berkembang seiring bertambahnya kebutuhan manusia yang semakin kompleks. Kemampuan yang dimiliki ini berkaitan dengan kecerdasan pribadi untuk bersikap efektif demi terwujudnya kesejahteraan masyarakat yang berkaitan dengan globalisasi yang tidak dapat kita hindari misalnya dalam hal menentukan keputusan masa depan yang berkaitan dengan keputusan jangka pendek ataupun jangka panjang secara tidak langsung.

Literasi keuangan merupakan suatu hal yang seharusnya menjadi kebutuhan dasar tiap- 
tiap individu atau masyarakat dalam mengelola keuangan. Hal ini dikarenakan apabila terjadi kesalahan dalam pengelolaan keuangan akan menimbulkan masalah dalam keuangan, contoh yang paling konkret adalah terjadinya kesulitan ekonomi. Kesulitan tidak hanya disebabkan oleh pengaruh pendapatan namun juga bisa disebabkan oleh kesalahan dalam pengelolaan keuangan (miss management). Oleh karena itu, literasi keuangan penting bagi masyarakat agar terhindar dari kesulitan ekonomi, termasuk bagi mahasiswa.

Menurut Otoritas Jasa Keuangan (OJK) Literasi keuangan merupakan pengetahuan, keterampilan, dan keyakinan yang mempengaruhi sikap dan perilaku untuk meningkatkan kualitas pengambilan keputusan dan pengelolaan keuangan dalam rangka mencapai kesejahteraan. ${ }^{1}$ Sikap dan perilaku keuangan yang bijak tercermin dalam kemampuan seseorang menentukan tujuan keuangan, menyusun perencanaan keuangan, mengelola keuangan dan mampu mengambil keputusan keuangan yang berkualitas dalam menggunakan produk layanan jasa keuangan.

Dalam rangka memperluas dan mempermudah akses masyarakat terhadap layanan keuangan, perlu adanya strategi khusus agar keuangan lebih inklusif. Inklusi keuangan merupakan salah satu cara untuk melakukan pemerataan ekonomi melalui fungsi intermediasi perbankan khususnya dalam hal ini adalah perbankan syariah, sebagaimana telah dijelaskan sebelumnya bahwa Indonesia merupkan negara kepulauan yang memungkinkan memiliki banyak hambatanhambatan dalam menerapkan inklusi keuangan, inklusi keuangan merupakan salah satu komitmen pemerintah untuk memberikan akses keuangan kepada semua lapisan masyarakat di Indonesia yang tertuang dalam strategi nasional keuangan inklusif.

Kendati demikian kinerja dan kondisi keuangan syariah relatif baik, seperti dalam penelitian yang dilakukan oleh Novia Ningsih. Hasil analisis perbandingan antar laporan keuangan dan analisis rasio mengindikasikan bahwa kinerja dan kondisi keuangan perbankan syariah baik. Pengimplementasian financial inclusion melalui perbankan syariah juga akan

\footnotetext{
${ }^{1}$ Otoritas Jasa Keuangan, Strategi Nasional Literasi Keuangan Indonesia, (Revisit 2017), hlm. 77.
}

didukung oleh produk-produk perbankan syariah yang melakukan operasional berdasarkan prinsip Islam dan mengemban misi sosial kemasyarakatan. ${ }^{2}$

Indeks inklusi keuangan syariah secara umum lebih tinggi dari indeks literasi keuangan syariah, dan tingkat inklusi dan literasi keuangan syariah masih sangat rendah dibanding konvensional, sehingga ada baiknya ke depan masyarakat dan mahasiswa khususnya perlu diberikan pengetahuan dan pemahaman terlebih dahulu mengenai jasa keuangan syariah sebelum mereka memanfaatkannya. Untuk lebih memahami tentang inklusi keuangan dan literasi keuangan syariah, maka sebagai mahasiswa, kita harus melanjutkan pendidikan selanjutnya yang berkaitan dengan hal tersebut ke Perguruan Tinggi. Pembelajaran literasi keuangan di Perguruan Tinggi didukung dengan adanya berbagai program studi yang akan mempermudah proses edukasi.

STAI Syekh H. Abdul Halim Hasan AlIshlahiyah Binjai merupakan salah satu sekolah tinggi swasta yang berada di Kota Binjai. STAI Al- Ishlahiyah Binjai memiliki beberapa program studi, salah satunya Perbankan Syariah. Inklusi dan literasi keuangan syariah Mahasiswa Perbankan Syariah di STAI AlIshlahiyah Binjai belum sepenuhnya baik, ini diperkuat dengan masih adanya mahasiswa yang menggunakan bank konvensional, dan ada juga yang menggunakan bank syariah dikarenakan untuk membayar administrasi kuliah menggunakan bank syariah. Selain itu pemahaman mengenai bank syariah sendiri pun masih dibutuhkan edukasi terkait bagaimana cara bertransaksi ataupun berinvestasi menggunakan bank syariah dan lain sebagainya.

Berdasarkan uraian di atas banyaknya penjelasan mengenai pentingnya inklusi dan literasi keuangan syariah dalam menggunakan lembaga keuangan syariah membuat mahasiswa terpacu untuk mempelajari lebih dalam mengenai hal tersebut, hal itulah yang mendorong penulis untuk melakukan penelitian yang berjudul "Pengaruh Inklusi dan Literasi Keuangan Syariah Terhadap Peningkatan Jumlah Mahasiswa Perbankan Syariah di STAI Al- Ishlahiyah Binjai".

\footnotetext{
${ }^{2}$ Novia Ningsih. 2015. Peran Perbankan Syariah Dalam Mengimplementasikan Keuangan Inklusif Di Indonesia. Etikonomi, Vol. 14, No. 2, hlm. 221-240
} 
Berdasarkan latar belakang di atas, penulis dapat mengidentifikasi masalah dalam penelitian ini, yaitu:

1. Tingkat inklusi dan literasi keuangan syariah masyarakat Sumatera Utara. Khususnya kota Binjai dan Langkat masih tergolong rendah jika dibandingkan dengan konvensional.

2. Rendahnya inklusi dan literasi keuangan syariah berdampak pada rendahnya penggunaan jasa keuangan syariah.

3. Peningkatan inklusi dan literasi keuangan syariah dapat dilakukan melalui edukasi keuangan di Perguruan Tinggi, sehingga diharapkan mahasiswa memiliki inklusi dan literasi keuangan syariah yang baik.

4. Mahasiswa perbankan yang notabenenya mengerti tentang keuangan seharusnya memiliki tingkat inklusi dan literasi keuangan syariah yang jauh lebih tinggi dibandingkan masyarakat pada umumnya yang tidak belajar lebih mengenai keuangan syariah.

\section{Metodologi Penelitian}

\subsection{Tempat dan Waktu Penelitian}

Penelitian ini dilakukan di Sekolah Tinggi Agama Islam (STAI) Syekh H. Abdul Halim Hasan Al- Ishlahiyah Binjai yang beralamat di Jl. Ir. H. Juanda No.5, Timbang Langkat, Kecamatan Binjai Timur, Kota Binjai, Sumatera Utara, Kode Pos 20735. Penelitian dilaksanakan mulai bulan Juni 2020 sampai dengan November 2020.

\subsection{Metode Penelitian}

Pendekatan yang digunakan dalam penelitian ini adalah pendekatan kuantitatif yaitu penelitian yang menekankan analisisnya pada data-data numerik atau angka yang diperoleh dengan metode statistik serta dilakukan pada penelitian dalam rangka pengujian hipotesis sehingga diperoleh signifikansi hubungan antara variabel yang diteliti. $^{3}$

\subsection{Populasi dan Sampling}

\subsubsection{Populasi}

Populasi diartikan sebagai wilayah generalisasi yang terdiri atas: obyek/ subyek yang mempunyai kualitas dan karakteristik tertentu yang ditetapkan oleh peneliti untuk dipelajari dan kemudian ditarik kesimpulannya. Sedangkan sampel adalah sebagian dari populasi itu. ${ }^{4}$ Berdasarkan pengertian tersebut, maka dapat ditetapkan yang menjadi populasi dalam penelitian ini adalah mahasiswa prodi Perbankan Syariah semester III, V, VII dan IX, keseluruhan berjumlah 1373 orang.

\subsubsection{Sampling}

Sampel merupakan bagian dari populasi yang ingin di teliti oleh peneliti. Sampel adalah bagian dari jumlah dan karakteristik yang dimiliki oleh populasi tersebut. Adapun untuk menentukan ukuran sampel dari suatu populasi menggunakan rumus Slovin, yaitu didapat hasil sampel sebanyak 93 responden.

\section{Hasil Penelitian \\ 3.1. Karakteristik Responden}

Hasil penelitian yang menggambarkan keadaan atau kondisi responden merupakan informasi tambahan untuk memahami hasilhasil penelitian. Responden dalam penelitian ini memiliki kerakteristik, dari hasil penyebaran kuesioner terhadap responden yang berkaitan dengan pengaruh inklusi dan literasi keuangan syariah terhadap peningkatan jumlah mahasiswa perbankan syariah di STAI AlIshlahiyah Binjai. Untuk memperjelas karakteristik yang dimaksud, maka akan disajikan tabel mengenai data responden dibawah ini :

a) Jenis Kelamin Responden

Responden dalam penelitian ini adalah mahasiswa program studi perbankan syariah semester III, V, VII, dan IX dengan jumlah sampel sebanyak 93 orang. Karakteristik responden berdasarkan jenis kelamin dapat dilihat sebagai berikut :

${ }^{3}$ Saifuddi Azwar, Metodologi Penelitian, (Yogyakarta: Pustaka Pelajar, 2004), hlm.5.

${ }^{4}$ Ibid., hlm. 215. 
Tabel 1 Karakteristik Berdasarkan Jenis Kelamin

\begin{tabular}{|c|c|c|c|c|c|c|c|c|c|c|c|}
\hline No & Jenis & \multicolumn{2}{|c|}{ SMT III } & \multicolumn{2}{|c|}{ SMT V } & \multicolumn{2}{|c|}{ SMT VII } & \multicolumn{2}{l|}{ SMT IX } & \multicolumn{2}{c|}{ TOTAL } \\
\cline { 3 - 12 } & Kelamin & $\mathrm{N}$ & $\%$ & $\mathrm{~N}$ & $\%$ & $\mathrm{~N}$ & $\%$ & $\mathrm{n}$ & $\%$ & $\mathrm{~N}$ & $\%$ \\
\hline 1. & Laki-laki & 10 & 36 & 8 & 36 & 7 & 33 & 10 & 46 & 35 & 38 \\
\hline 2. & Perempuan & 18 & 64 & 14 & 64 & 14 & 67 & 12 & 54 & 58 & 62 \\
\hline & Jumlah & 28 & 100 & 22 & 100 & 21 & 100 & 22 & 100 & 93 & 100 \\
\hline
\end{tabular}

Sumber : Data Primer, diolah 2020

Karakteristik responden berdasarkan jenis kelamin dikelompokkan ke dalam dua kelompok, yaitu kelompok laki-laki dan perempuan, sebagaimana yang ditampilkan pada tabel 1 di atas dapat ditunjukkan bahwa dari 93 responden untuk jenis kelamin laki-laki sebanyak 35 responden, dengan persentase $38 \%$ dan perempuan sebanyak 58 responden, dengan persentase $62 \%$.

b) Tingkat Usia

Karakteristik responden berdasarkan tingkat usia dapat dilihat sebagai berikut :

Tabel 2 Karakteristik Responden Berdasarkan Tingkat Usia

\begin{tabular}{|c|c|c|c|}
\hline No. & Usia (Tahun) & Jumlah & Persentase \\
\hline 1. & $17-20$ & 50 & $54 \%$ \\
\hline 2. & $21-25$ & 43 & $46 \%$ \\
\hline 3. & $26-30$ & 0 & $0 \%$ \\
\hline & Total & 93 & $100 \%$ \\
\hline
\end{tabular}

Sumber : Data Primer, diolah 2020

Dari keterangan tabel $2 \mathrm{di}$ atas dapat dilihat bahwa usia responden didominasi oleh usia antara $17-20$ tahun yang berjumlah 50 orang, dengan persentase $54 \%$ dan kelompok usia 21 - 25 tahun berjumlah 43 orang, dengan persentase $46 \%$. c) Semester

Karakteristik responden berdasarkan tingkat semester responden dapat dilihat sebagai berikut:

Tabel 3 Karakteristik Responden Berdasarkan Tingkat Semester

\begin{tabular}{|c|c|c|c|}
\hline No. & Semester & Jumlah & Persentase \\
\hline 1. & III & 28 & $30,1 \%$ \\
\hline 2. & V & 22 & $23,7 \%$ \\
\hline 3. & VII & 21 & $22,5 \%$ \\
\hline 4. & IX & 22 & $23,7 \%$ \\
\hline & Total & 93 & $100 \%$ \\
\hline
\end{tabular}

Dari keterangan tabel 3 di atas dapat dilihat bahwa tingkat semester responden untuk semester III sebanyak 28 orang dengan persentase $30,1 \%$, semester $\mathrm{V}$ sebanyak 22 orang dengan persentase $23,7 \%$, semester VII sebanyak 21 orang dengan persentase $22,5 \%$,

dan semester IX sebanyak 22 orang dengan persentase $23,7 \%$.

d) Domisili

Karakteristik responden berdasarkan domisili dapat dilihat sebagai berikut:

Tabel 4 Karakteristik Responden Berdasarkan Domisili

\begin{tabular}{|c|c|c|c|}
\hline No. & Domisili & Jumlah & Persentase \\
\hline 1. & Binjai & 63 & $67,7 \%$ \\
\hline 2. & Langkat & 24 & $25,8 \%$ \\
\hline 3. & Deli Serdang & 6 & $6,5 \%$ \\
\hline & Total & 93 & $100 \%$ \\
\hline
\end{tabular}

Sumber : Data Primer, diolah 2020

Berdasarkan keterangan pada tabel 4 memperlihatkan sebagian besar responden berdomisili di Binjai sebanyak 63 orang, dengan persentase $67,7 \%$, Langkat sebanyak 24 orang, dengan persentase $25,8 \%$ dan Deli Serdang sebanyak 6 orang, dengan persentase $6,5 \%$. 


\subsection{Deskripsi Variabel}

Berikut ini adalah deskripsi tentang data yang diperoleh melalui penyebaran kuisioner kepada responden yang berkaitan dengan pengaruh inklusi dan literasi keuangan syariah terhadap peningkatan jumlah mahasiswa perbankan syariah di STAI Al-Ishlahiyah Binjai. Variabel yang dijelaskan berikut ini adalah variabel yang berkaitan dengan pengaruh inklusi dan literasi keuangan syariah dan peningkatan jumlah mahasiswa perbankan syariah. Jumlah responden dalam penelitian ini adalah sebanyak 93 orang.

a. Data Variabel Pengaruh Inklusi $\left(\mathrm{X}_{1}\right)$ dan Literasi Keuangan Syariah $\left(\mathrm{X}_{2}\right)$

Variabel Inklusi $\left(\mathrm{X}_{1}\right)$ terbagi menjadi tiga (3) indikator, yang terdiri dari 10 item pertanyaan dan Variabel Literasi Keuangan Syariah $\left(\mathrm{X}_{2}\right)$ terbagi menjadi dua (2) indikator, yang terdiri dari 10 item pertanyaan. b. Data Variabel Peningkatan Jumlah Mahasiswa Perbankan Syariah (Y)

Variabel peningkatan Jumlah Mahasiswa Perbankan Syariah (Y) terbagi menjadi tiga (3) indikator, yang terdiri dari 10 item pertanyaan.

\section{Hasil Uji Keabsahan Data 4.1. Uji Validitas}

Uji validitas adalah uji yang digunakan untuk mengukur valid tidaknya suatu kuesioner. Suatu kuesioner dikatakan valid jika pertanyaan pada kuesioner mampu untuk mengungkapkan sesuatu yang akan diukur oleh kuesioner tersebut.

Untuk melakukan uji validitas ini, penulis menggunakan program SPSS versi 22. Teknik pengujian yang digunakan adalah menggunakan korelasi Bivariate Pearson (Produk Momen Person). Analisis ini dengan cara mengkorelasikan masing-masing skor item dengan skor total.

Tabel 5 Hasil Uji Validitas Angket Inklusi (X1)

Item-Total Statistics

\begin{tabular}{|l|r|r|r|r|}
\hline & $\begin{array}{c}\text { Scale Mean if } \\
\text { Item Deleted }\end{array}$ & $\begin{array}{c}\text { Scale Variance if } \\
\text { Item Deleted }\end{array}$ & $\begin{array}{c}\text { Corrected Item- } \\
\text { Total Correlation }\end{array}$ & $\begin{array}{c}\text { Cronbach's Alpha if } \\
\text { Item Deleted }\end{array}$ \\
\hline INK1 & 35.7419 & 35.259 & .570 & .925 \\
\hline INK2 & 35.7527 & 33.036 & .815 & .912 \\
\hline INK3 & 35.7527 & 33.036 & .815 & .912 \\
\hline INK4 & 35.7419 & 35.259 & .570 & .925 \\
\hline INK5 & 35.8495 & 33.108 & .780 & .914 \\
\hline INK6 & 35.7527 & 33.036 & .815 & .912 \\
\hline INK7 & 35.7527 & 33.036 & .815 & .912 \\
\hline INK8 & 35.7419 & 35.259 & .570 & .925 \\
\hline INK9 & 35.7527 & 33.036 & .815 & .912 \\
\hline INK10 & 35.7419 & 35.259 & .570 & .925 \\
\hline
\end{tabular}

Sumber : data diolah menggunakan SPSS 22

Tabel 6 Hasil Uji Validitas Angket Literasi Keuangan Syariah (X2)

Item-Total Statistics

\begin{tabular}{|l|r|r|r|r|}
\hline & $\begin{array}{c}\text { Scale Mean if } \\
\text { Item Deleted }\end{array}$ & $\begin{array}{c}\text { Scale Variance if } \\
\text { Item Deleted }\end{array}$ & $\begin{array}{c}\text { Corrected Item- } \\
\text { Total Correlation }\end{array}$ & $\begin{array}{c}\text { Cronbach's Alpha if } \\
\text { Item Deleted }\end{array}$ \\
\hline LTR1 & 36.9032 & 17.327 & .576 & .808 \\
\hline LTR2 & 37.0000 & 17.717 & .525 & .814 \\
\hline LTR3 & 36.8602 & 18.143 & .487 & .817 \\
\hline LTR4 & 37.0645 & 18.365 & .447 & .821 \\
\hline LTR5 & 37.0215 & 17.543 & .539 & .812 \\
\hline LTR6 & 37.0645 & 17.952 & .506 & .816 \\
\hline LTR7 & 37.0108 & 17.685 & .566 & .810 \\
\hline LTR8 & 37.0215 & 18.717 & .401 & .825 \\
\hline LTR9 & 36.9785 & 17.326 & .555 & .811 \\
\hline LTR10 & 36.9462 & 17.573 & .566 & .810 \\
\hline
\end{tabular}

Sumber : data diolah menggunakan SPSS 22 
Tabel 7 Hasil Uji Validitas Angket Peningkatan Jumlah

Mahasiswa Perbankan Syariah (Y)

Item-Total Statistics

\begin{tabular}{|l|r|r|r|r|}
\hline & $\begin{array}{c}\text { Scale Mean if } \\
\text { Item Deleted }\end{array}$ & $\begin{array}{c}\text { Scale Variance } \\
\text { if Item Deleted }\end{array}$ & $\begin{array}{c}\text { Corrected Item- } \\
\text { Total Correlation }\end{array}$ & $\begin{array}{c}\text { Cronbach's Alpha if } \\
\text { Item Deleted }\end{array}$ \\
\hline PJM1 & 33.1505 & 19.108 & .548 & .794 \\
\hline PJM2 & 33.2473 & 19.145 & .470 & .803 \\
\hline PJM3 & 33.2688 & 18.677 & .609 & .788 \\
\hline PJM4 & 33.3226 & 19.373 & .465 & .803 \\
\hline PJM5 & 33.0538 & 20.182 & .518 & .800 \\
\hline PJM6 & 33.3978 & 19.503 & .470 & .803 \\
\hline PJM7 & 33.3656 & 19.365 & .495 & .800 \\
\hline PJM8 & 33.3548 & 19.514 & .440 & .806 \\
\hline PJM9 & 33.2796 & 19.399 & .437 & .807 \\
\hline PJM10 & 33.1720 & 19.057 & .549 & .794 \\
\hline
\end{tabular}

Sumber : data diolah menggunakan SPSS 22

Dari tabel-tabel di atas dapat disimpulkan bahwa instrumen atau item-item pada kuesioner tersebut dinyatakan valid, dilihat dari nilai corrected item-total correlation $>0,3$.

\subsection{Uji Reliabilitas}

Reliabilitas instrumen diperlukan untuk mendapatkan data sesuai dengan tujuan pengukuran. Untuk mencapai hal tersebut, dilakukan uji reliabilitas dengan menggunakan skala Alpha Cronbach's 0 sampai dengan 1.berikut hasil dari pengujian reliabilitas dapat dilihat pada tabel dibawah ini :

Tabel 8 Hasil Uji Reliabilitas Instrument Inklusi

\begin{tabular}{|c|c|}
\hline \multicolumn{2}{|c|}{ Reliability Statistics } \\
\hline Cronbach's Alpha & N of Items \\
\hline .925 & 10 \\
\hline
\end{tabular}

Sumber : data diolah menggunakan SPSS 22

Tabel 9 Hasil Uji Reliabilitas Instrument Literasi Keuangan Syariah

\begin{tabular}{|c|c|}
\hline \multicolumn{2}{|c|}{ Reliability Statistics } \\
\hline Cronbach's Alpha & N of Items \\
\hline .830 & 10 \\
\hline
\end{tabular}

Sumber : data diolah menggunakan SPSS 22

b) Jika data menyebar jauh dari garis diagonal dan tidak mengikuti arah garis diagonal, maka model garis regresi tidak memenuhi asumsi normalitas.

Setelah menganalisis dengan SPSS, hasil output pada gambar "Normal P-P Plot of Regression Standardized Residual", adalah seperti berikut :
Tabel 10 Hasil Uji Reliabilitas Instrument Peningkatan Jumlah Mahasiswa Perbankan Syariah

\begin{tabular}{|c|c|}
\hline \multicolumn{2}{|c|}{ Reliability Statistics } \\
\hline Cronbach's Alpha & N of Items \\
\hline .816 & 10 \\
\hline
\end{tabular}

Sumber : data diolah menggunakan SPSS 22

Berdasarkan tabel-tabel di atas, untuk masing-masing variabel, nilai Alpha Cronbach's > 0,60 maka dapat disimpulkan bahwa alat ukur dalam penelitian ini sangat reliabel.

\section{Uji Asumsi Klasik}

\subsection{Uji Normalitas Data}

Uji normalitas dilakukan dengan mengamati penyebaran data pada sumbu diagonal grafik. Metode yang digunakan adalah metode p plot.

Cara pengambilan keputusannya pada metode $\mathrm{p}$ plot adalah :

a) Jika data menyebar disekitar garis diagonal dan mengikuti arah garis diagonal, maka model garis regresi memenuhi asumsi normalitas.

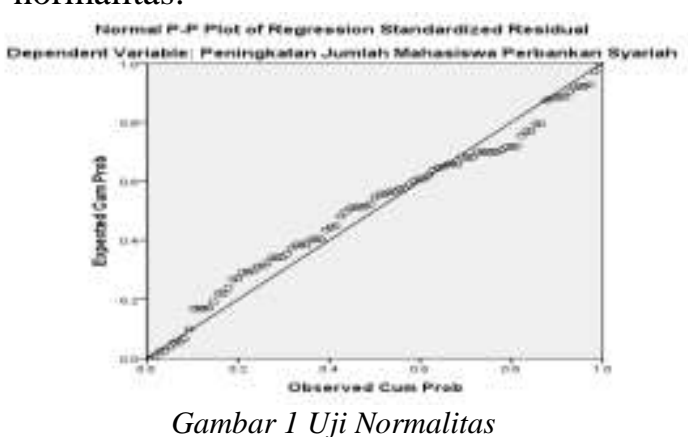


Dari gambar di atas dapat dilihat bahwa data menyebar di sekitar garis diagonal dan mengikuti arah garis diagonal, maka data terdistribusi dengan normal dan model regresi telah memenuhi asumsi normalitas.

\subsection{Uji Multikolinearitas}

Untuk mendeteksi ada tidaknya multikolinearitas dengan melihat nilai Tolarance dan VIF. Semakin kecil nilai Tolerance dan semakin besar VIF maka semakin mendekati terjadinya masalah multikolinearitas. Dalam kebanyakan penelitian menyebutkan bahwa jika Tolarance $>0,1$ dan VIF $<10$ maka tidak terjadi multikolinearitas.

Tabel 11 Hasil Uji Multikolinearitas Coefficients $^{\mathrm{a}}$

\begin{tabular}{|c|c|c|}
\hline \multirow[b]{2}{*}{ Model } & \multicolumn{2}{|c|}{ Collinearity Statistics } \\
\hline & Tolerance & VIF \\
\hline (Constant) & & \\
\hline $\begin{array}{ll}1 & \text { Inklusi }\end{array}$ & .335 & 2.982 \\
\hline $\begin{array}{l}\text { Literasi Keuangan } \\
\text { Syariah }\end{array}$ & .335 & 2.982 \\
\hline
\end{tabular}

Berdasarkan tabel di atas, dapat diketahui bahwa nilai Tolarance dari kedua variabel independen $>0,1$ dan VIF $<10$, jadi dapat disimpulkan bahwa dalam model regresi tidak terjadi masalah multikolinearitas.

\subsection{Uji Heteroskedastisitas}

Untuk mendeteksi ada tidaknya heteroskedastisitas dengan melihat pola titiktitik pada scatterplots regresi. Jika titik-titik menyebar dengan pola tidak jelas di atas dan di bawah angka 0 pada sumbu $\mathrm{Y}$ maka tidak terjadi masalah heteroskedastisitas. Scaterrplot dapat dilihat pada output regresi dibawah ini.

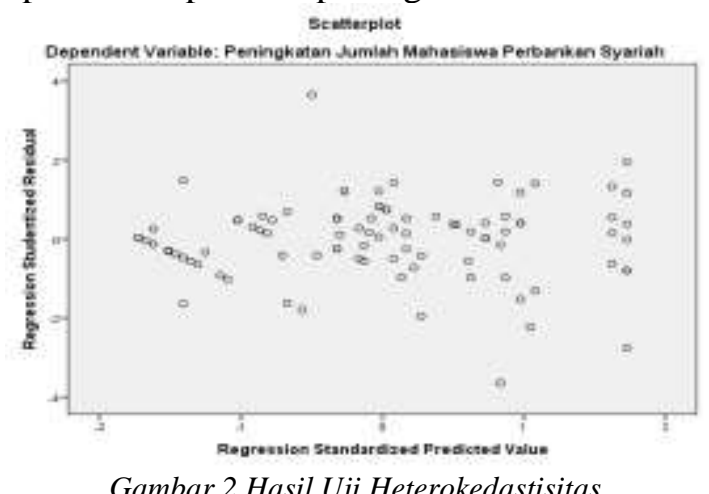

Dari Scatterplot di atas dapat diketahui bahwa titik-titik menyebar dengan pola yang tidak jelas di atas dan di bawah angka 0 pada sumbu Y, maka pada model regresi tidak terjadi masalah heteroskedastisitas.

\section{Uji Regresi Linier Berganda}

Hasil pengujian pengaruh variabel independen (inklusi dan literasi keuangan syariah) terhadap variabel dependen (peningkatan jumlah mahasiswa perbankan syariah).

Tabel 12 Hasil Uji Regresi Berganda

\begin{tabular}{|l|r|r|r|r|r|}
\hline \multirow{2}{*}{ Model } & \multicolumn{2}{|c|}{$\begin{array}{c}\text { Unstandardized } \\
\text { Coefficients }\end{array}$} & $\begin{array}{c}\text { Standardized } \\
\text { Coefficients }\end{array}$ & \multirow{2}{*}{$\mathrm{T}$} & \multirow{2}{*}{ Sig. } \\
\cline { 2 - 5 } & \multicolumn{1}{c|}{$\mathrm{B}$} & Std. Error & Beta & & \\
\hline (Constant) & 8.199 & 2.472 & & 3.317 & .001 \\
1Inklusi & .502 & .073 & .668 & 6.873 & .000 \\
Literasi Keuangan Syariah & .215 & .101 & .207 & 2.124 & .036 \\
\hline
\end{tabular}

Sumber : data diolah menggunakan SPSS 22

Berdasarkan hasil pengujian parameter individual yang disajikan dalam gambar di atas, maka dapat dikembangkan model persamaan regresi:

$$
Y=8,199+0,502 X_{1}+0,215 X_{2}
$$

Dari persamaan regresi di atas, maka dapat diuraikan sebagai berikut :

a. Konstanta sebesar 8,199 menunjukkan nilai peningkatan jumlah mahasiswa perbankan syariah sebelum dipengaruhi oleh variabel inklusi dan literasi keuangan syariah adalah positif.

b. Koefisien $\mathrm{b}_{1}=0,502$ menunjukkan peningkatan 1 skor inklusi akan meningkatkan jumlah mahasiswa perbankan syariah sebesar 0,502 dengan asumsi variabel-variabel bebas lainnya konstan. Koefisien bernilai positif artinya terjadi pengaruh positif antara inklusi dengan peningkatan jumlah mahasiswa perbankan 
syariah, semakin baik inklusinya maka semakin meningkat jumlah mahasiswa perbankan syariah.

c. Koefisien $\mathrm{b}_{2}=0,215$ menunjukkan peningkatan 1 skor literasi keuangan syariah akan meningkatkan jumlah mahasiswa perbankan syariah sebesar 0,215 dengan asumsi variabel-variabel bebas lainnya konstan. Koefisien bernilai positif artinya terjadi pengaruh positif antara literasi keuangan syariah dengan peningkatan jumlah mahasiswa perbankan syariah, semakin baik literasi keuangan syariah maka semakin meningkat jumlah perbankan syariah.

\section{Uji Hipotesis}

\subsection{Uji T (Uji Parsial)}

Uji $\mathrm{T}$ digunakan untuk menguji apakah variabel independen berpengaruh secara parsial terhadap variabel dependen. Berdasarkan hasil statistik dari tabel 4.12 di atas, dapat ditarik kesimpulan bahwa :

1) Hipotesis pertama dalam penelitian ini adalah, Inklusi $\left(\mathrm{X}_{1}\right)$ berpengaruh positif dan signifikan terhadap Peningkatan Jumlah Mahasiswa Perbankan Syariah (Y). Berdasarkan hasil uji regresi berganda pada tabel 12 di atas diketahui bahwa $b_{1}$ Inklusi bernilai positif sebesar 0,502 dan nilai $\mathrm{t}_{\text {hitung }}>$ $t_{\text {tabel }}$ yaitu sebesar 6,873 > 1,986 dengan tingkat signifikansi $0,000<0,05$. Hal ini menunjukkan bahwa Inklusi berpengaruh positif dan signifikan terhadap Peningkatan Jumlah Mahasiswa Perbankan Syariah. Dengan demikian hipotesis pertama $\left(\mathrm{Ha}_{1}\right)$ diterima.

2) Hipotesis kedua dalam penelitian ini adalah, Inklusi $\left(\mathrm{X}_{1}\right)$ tidak berpengaruh positif dan signifikan terhadap Peningkatan Jumlah Mahasiswa Perbankan Syariah (Y). Berdasarkan hasil uji regresi berganda pada tabel 12 di atas diketahui bahwa $b_{1}$ Inklusi bernilai positif sebesar 0,502 dan nilai $t_{\text {hitung }}>$ $t_{\text {tabel }}$ yaitu sebesar 6,873 $>1,986$ dengan tingkat signifikansi $0,000<0,05$. Hal ini menunjukkan bahwa Inklusi berpengaruh positif dan signifikan terhadap Peningkatan Jumlah Mahasiswa Perbankan Syariah. Dengan demikian hipotesis pertama $\left(\mathrm{Ho}_{1}\right)$ ditolak.

3) Hipotesis ketiga pada penelitian ini adalah, Literasi Keuangan Syariah $\left(\mathrm{X}_{2}\right)$ berpengaruh positif dan signifikan terhadap Peningkatan Jumlah Mahasiswa Perbankan Syariah (Y). Berdasarkan hasil uji regresi berganda pada tabel 12 di atas diketahui bahwa $b_{2}$ Literasi Keuangan Syariah bernilai positif sebesar 0,460 dan nilai $t_{\text {hitung }}>t_{\text {tabel }}$ yaitu sebesar 2,124>1,986 dengan tingkat signifikansi $0,036<0,05$. Hal ini menunjukkan bahwa Literasi Keuangan Syariah berpengaruh positif dan signifikan terhadap Peningkatan Jumlah Mahasiswa Perbankan Syariah. Dengan demikian hipotesis kedua $\left(\mathrm{Ha}_{2}\right)$ diterima.

4) Hipotesis keempat pada penelitian ini adalah, Literasi Keuangan Syariah $\left(\mathrm{X}_{2}\right)$ tidak berpengaruh positif dan signifikan terhadap Peningkatan Jumlah Mahasiswa Perbankan Syariah (Y). Berdasarkan hasil uji regresi berganda pada tabel 12 di atas diketahui bahwa $b_{2}$ Literasi Keuangan Syariah bernilai positif sebesar 0,460 dan nilai $t_{\text {hitung }}>t_{\text {tabel }}$ yaitu sebesar 2,124>1,986 dengan tingkat signifikansi $0,036<0,05$. Hal ini menunjukkan bahwa Literasi Keuangan Syariah berpengaruh positif dan signifikan terhadap Peningkatan Jumlah Mahasiswa Perbankan Syariah. Dengan demikian hipotesis kedua $\left(\mathrm{Ho}_{2}\right)$ ditolak.

\subsection{Uji F}

Uji $\mathrm{F}$ digunakan untuk menguji pengaruh variabel bebas terhadap variabel terikat secara bersama-sama. Dapat dilihat pada tabel 4.10 dibawah ini.

Tabel 13 Hasil Uji F Statistik ANOVA $^{\mathrm{a}}$

\begin{tabular}{|l|r|r|r|r|r|}
\hline Model & Sum of Squares & Df & \multicolumn{1}{|c|}{$\begin{array}{c}\text { Mean } \\
\text { Square }\end{array}$} & F & Sig. \\
\hline Regression & 1537.653 & 2 & 768.827 & 112.662 & $.000^{\mathrm{b}}$ \\
Residual & 614.175 & 90 & 6.824 & & \\
Total & 2151.828 & 92 & & & \\
\hline
\end{tabular}

a. Dependent Variable: Peningkatan Jumlah Mahasiswa Perbankan Syariah

b. Predictors: (Constant), Literasi Keuangan Syariah, Inklusi 
Dari tabel di atas dapat dilihat nilai $\mathrm{F}_{\text {hitung }}$ sebesar 112,662 dengan tingkat signifikansi 0,000 . Oleh karena itu probabilitas jauh lebih kecil dari taraf signifikansi sebesar 0,05 atau $5 \%$ dan $F_{\text {hitung }}$ jauh lebih besar dari nilai $\mathrm{F}_{\text {tabel }} 2,71$. Dengan demikian maka, dapat disimpulkan bahwa :

1) Hipotesis kelima pada penelitian ini adalah inklusi $\left(\mathrm{X}_{1}\right)$ dan literasi keuangan syariah $\left(\mathrm{X}_{2}\right)$ berpengaruh secara bersama-sama terhadap Peningkatan Jumlah Mahasiswa Perbankan Syariah (Y). Berdasarkan tabel di atas dapat dilihat bahwa nilai $\mathrm{F}_{\text {hitung }}>\mathrm{F}_{\text {tabel }}$ sebesar 112,662 > 2,71 dengan tingkat signifikan $0,000<0,05$. Dengan demikian maka dapat disimpulkan bahwa hipotesis kelima $\left(\mathrm{Ha}_{3}\right)$ diterima, yang berarti terdapat pengaruh yang signifikan secara bersamasama dari Inklusi dan Literasi Keuangan Syariah terhadap Peningkatan Jumlah Mahasiswa Perbankan Syariah.
2) Hipotesis keenam pada penelitian ini adalah inklusi $\left(\mathrm{X}_{1}\right)$ dan literasi keuangan syariah $\left(\mathrm{X}_{2}\right)$ tidak berpengaruh secara bersama-sama terhadap Peningkatan Jumlah Mahasiswa Perbankan Syariah (Y). Berdasarkan tabel di atas dapat dilihat bahwa nilai $F_{\text {hitung }}>F_{\text {tabel }}$ sebesar 112,662 > 2,71 dengan tingkat signifikan $0,000<0,05$. Dengan demikian maka dapat disimpulkan bahwa hipotesis keenam $\left(\mathrm{Ho}_{3}\right)$ ditolak, yang berarti tidak terdapat pengaruh yang signifikan secara bersama-sama dari Inklusi dan Literasi Keuangan Syariah terhadap Peningkatan Jumlah Mahasiswa Perbankan Syariah.

\subsection{Analisis Koefisien Determinasi $\left(\mathbf{R}^{2}\right)$}

Analisis ini digunakan untuk mengetahui seberapa besar sumbangan atau kontribusi variabel independen terhadap variabel dependen.

Tabel 14. Hasil Uji Koefisien Determinasi

Model Summary ${ }^{\mathrm{b}}$

\begin{tabular}{|l|r|r|r|r|}
\hline Model & \multicolumn{1}{|c|}{$\mathrm{R}$} & \multicolumn{1}{|c|}{ R Square } & \multicolumn{1}{c|}{$\begin{array}{c}\text { Adjusted R } \\
\text { Square }\end{array}$} & Std. Error of the Estimate \\
\hline 1 & $.845^{\mathrm{a}}$ & .715 & .708 & 2.61231 \\
\hline
\end{tabular}

a. Predictors: (Constant), Literasi Keuangan Syariah, Inklusi

b. Dependent Variable: Peningkatan Jumlah Mahasiswa Perbankan Syariah

Sumber : data diolah menggunakan SPSS 22

Berdasarkan pada tabel 14 di atas dapat diketahui bahwa nilai $\mathrm{R}$ adalah sebesar 0,845 , maka koefisien determinasi (R Square) adalah sebesar $0,845 \times 0,845=0,715$ atau $71,5 \%$ artinya peningkatan jumlah mahasiswa perbankan syariah dapat dijelaskan oleh inklusi dan literasi keuangan syariah. Sedangkan sisanya $28,5 \%$ dapat dijelaskan oleh faktorfaktor lain.

\section{Pembahasan}

Penelitian ini menggunakan 3 (tiga) variabel yang terdiri dari 2 (dua) variabel bebas $\left(\mathrm{X}_{1}\right)$ Inklusi dan $\left(\mathrm{X}_{2}\right)$ Literasi Keuangan Syariah, dengan 1 (satu) variabel terikat (Y) Peningkatan Jumlah Mahasiswa Perbankan Syariah. Penelitian ini menggunakan data primer yang diperoleh dari penyebaran kuesioner/angket dengan jumlah sampel 93 orang/responden.

Berdasarkan hasil penelitian baik secara teori pada bab 2 maupun dengan pengujian data menggunakan SPSS menunjukkan bahwa pengaruh inklusi dan literasi keuangan syariah terhadap peningkatan jumlah mahasiswa perbankan syariah cukup baik dengan persentase $71,5 \%$ melalui uji $\mathrm{R}^{2}$. Merujuk pada hasil uji validasi dan reliabilitas alat ukur dalam penelitian ini bisa dikatakan valid karena $r_{\text {hitung }}>$ $\mathrm{r}_{\text {tabel. }}$. Dan alat ukur dalam penelitian ini dapat dikatakan sangat reliabel karena nilai Alpha Cronbach's untuk masing-masing variabel di atas 0,60 .

\section{Kesimpulan}

Berdasarkan hasil penelitian dan pembahasan pada Bab IV dapat disimpulkan sebagai berikut :

1) Pengaruh inklusi dan literasi keuangan syariah terhadap peningkatan jumlah mahasiswa perbankan syariah di STAI AlIshlahiyah Binjai dapat dikatakan baik berdasarkan hasil Uji $\mathrm{R}^{2}$ menunjukkan bahwa nilai $\mathrm{R}=0,845$ dan $\mathrm{R} \times \mathrm{R}=\mathrm{R}^{2}$ sebesar 0,715 atau $71,5 \%$. Dari hasil ini menunjukkan tingkat inklusi dan literasi 
keuangan syariah mahasiswa perbankan syariah dapat dinyatakan baik.

2) Dari hasil uji $R^{2}$ yang menghasilkan $71,5 \%$, persantase ini menunjukkan bahwa inklusi dan literasi keuangan syariah terhadap peningkatan jumlah mahasiswa perbankan syariah di STAI Al-Ishlahiyah Binjai, namun hasil analisa ini belum memuaskan. Karena hanya meraih angka $71,5 \%$, ini artinya masih ada yang harus diperbaiki dan dievaluasi di tahun-tahun mendatang untuk meningkatkan tingkat inklusi dan literasi keuangan syariah mahasiswa perbankan syariah di STAI Al-Ishlahiyah Binjai.

3) Berdasarkan uji $T$ (Parsial), dengan jumlah sampel sebanyak 93 responden, nilai $t_{\text {hitung }}>$ $\mathrm{t}_{\text {tabel }}$ untuk variabel $\mathrm{X}_{1}$ sebesar $6,873>1,986$ dengan tingkat signifikansi $0,000<0,05$. Dan nilai $t_{\text {hitung }}>t_{\text {tabel }}$ untuk variabel $X_{2}$ sebesar $2,124>1,986$ dengan tingkat signifikansi $0,036<0,05$. Artinya secara parsial variabel $X_{1}$ dan $X_{2}$ berpengaruh terhadap variabel $Y$ yaitu peningkatan jumlah mahasiswa perbankan syariah. Dan untuk uji $F$ (Simultan) nilai $F_{\text {hitung }}>F_{\text {tabel }}$ sebesar 112,662 > 2,71 dengan tingkat signifikan $0,000<0,05$. Ini membuktikan bahwa secara simultan inklusi dan literasi keuangan syariah mempengaruhi meningkatnya jumlah mahasiswa perbankan syariah di STAI Al-Ishlahiyah Binjai.

\section{DAFTAR PUSTAKA}

Otoritas Jasa Keuangan, Strategi Nasional Literasi Keuangan Indonesia, (Revisit 2017.

Novia Ningsih. 2015. Peran Perbankan Syariah Dalam Mengimplementasikan Keuangan Inklusif Di Indonesia. Etikonomi, Vol. 14, No. 2.

Azwar, Saifuddi. MetodologiPenelitian, Yogyakarta: PustakaPelajar, 2004.

Sugiyono, Metode Penelitian Kuantitatif, Kualitatif dan $R \& D$, Bandung: Alfabeta, 2018.

Priyatno, Duwi. SPSS Untuk Analisis Korelasi, Regresi, dan Multivariate, Yogyakarta : Gava Media, 2009. 